uppronched the medinn line of the skull, involving the first temporosphenoidnl convolution, which wonld account for the partinl deafness, the supramnrginnl nad aagular conrolutions, and possibly the cuneus licoce the homonymous hemisnopia.

The conjugate devintion of the oyes is not ensily explained if it is assumed that this phenomenon depends on injury to the second froata] convolution, as the wound was situnted some distance behind and below this convolution. The third frontal convolution might have heen involved in the lesion, so it seems fnir in this case to nttribute the conjugate devintion to injury of this convolution.

The loss of tactile sensation in the left hand, and to $a$ less degree in the foot, was to be expected from injury to the posterior motor arca. According to Starr, " the parts susceptible of the fiaest and most dclicate movements, those directed hy the most acute censntions-the lips, the fingers, and the toes-lie furtbest hack in the motor aren, chicfly in the posterior central convolution. Lesions in this convolution almost always cnuse some loss of tactile seasation as wcll as paralysis."

As the patient was right-handed and the injury was on the riglit side tliere were no aymptoms of nphasin-no iaterfereace with memory of any kind-as there would undoubtedly have beeu had the same lesion occurred ou the left side.

\title{
TUBERCULOSIS OF THE PORTIO VAGINALIS AND CERYIX UTERI; ITS PATHOLOGY, DIAGNOSIS, AND TREATMEN'I.
}

By HeNnY D. BEYEA, M.D.,

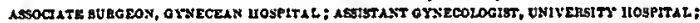
ISISTEVCTOB IY GYNECOLOGY, UNITERSITY OP PENSBYLYANIA.

Tunencutosis of the female genital organs has hcen known to the medical profession for many years. Raymond, a Freoch writer, and others, described lesions of thesc organs as early as 1831 . Such studies, and those during more than fifty yenrs following, wcre simply discoveries of far advaneed lesions in suhjects dying of phtlisis or more or less general tuherculosis. They were of interest only to the pathologist. It was then helieved, ns was asserted hy Lebert nnd Rokitansky, thnt the dingnosis of genital tuberculosis in the living femule was not possible. The first puhlicatiou worthy of notiec which considered the disease in this part of the body from a clinical stand-point, fully warnatiag the contradiction of the nhove statement, was the monograph of Hegar (1886), entitled Die Entstehung, Diagnose und chirurgische Behandlung der Genital tuberkulose des lVeibes. This work distioctly marks an epoch of advance in our knowledgc of the early pathology, dingaosis, and treat-

1 Read before the Thirteenth Internallonal Congress of Medicine, Faris. 
ment of geuital tubereulosis, and it has formed a groundwork for more nccurnte nad extensive practical studies during the sueceeding years. 'The collaboration of the literature and personnl studies of tuberculosis of the Fallopinn tubes, ovaries, nad vaginn are now frequently in evideace, and it may be said that at present their pnthology nnd clinical significance is as well apprecinted as tbnt of tuberculosis in any other part of the hody.

Tuberculosis of the portio vagianlis and cervix uteri, however, hnve not met with the same degree of consideration, though clinically at least of equal importanee. Tubercular infcetion here is of very rare oceurreace, but it has seemed to the writer that the pathology, symptomntology, and treatmeat of a sufficicit aumber of cases bave now becu carefully described to afford deductious wbich nre of practicnl valuc.

My studies in this direetion, of which I can here offer only $n$ short résumé of conelusions, was iustigated hy the clinical observation and pathologienl studies of oue instanee of the disense, followed by a careful surfey of tbirty tiwo post-mortem, twenty-two clinieal, and fifteen elinicul nad post-mortem observations taken from tbe literature.

Tho case eoming under my aotice was admitted to the Univereity Hospital on Mnreh 27, 1899. The patient was an Americna whito woinan, aged tweaty-three years. Her previous perenal nnd fnmily listory was good and free from tuhereulosis. Fer bushnnd was healthy. Slie was married in Oetober, 1898, but was never pregant. Menstruntion appenred nt eigliteen years of nge, hut was very slight in nmount, und oeeurred only every two, three, or five monthe. She had not menstruated siace marringe. Leucorrhon, profuse and extremely offeasive, had heen present for three years. There was a slight disehnrge of blood on two oecasions after sexual intercourse. Since puherty, uneonnected with the menstrunl period, sbe had experienced every month or two mild nttaeks of aehing pnin in the left inguinal region, whieh seemed to be induced by exercise. She helieved ber present illness to date from niaeteen years of age, nad since thcu she had gradunlly fniled in health. Tro weeks before eoming under observation she was takell with severe pain in the left side of the ahdomen, backnehe, frontal hendache, and pain in the lower extremities, had fever nud a rapid pulse, was auch exhausted, nad compelled to go to hed. After a few days' trcatment for ln grippe she was better and able to be out of bed, but, becausc of continued pain in the left side and the presence of a profusc aud offensive mucopurulent vaginal discharge, ber phyzicinu suspected uterine and ovarian discase, nad accordiagly made a vaginal examinntion. He found the vaginal cervix hard and indurnted and tbe sent of a growth which bled easily to touch. Considering these local symptoms highly suspicious of carcinoma of the eervix, he traasferred the patient to my care. 
Ou admission to the hospital the patient still complained of considerable pain in the left inguinul region, sncral hacknclie, frontal headnclie, loss of strength, and general malnise. A careful study of the urine determined it to be unicroscopically and chemically normal.

Vagisal Exsminstion. The vaginal outlet and vagina were nullipnrous and normul. The vaginal cervix was irregular in shape and very much hypertrophied, heing nearly twice the normal size. The mncous memhrane of the portin vaginnlis for a distance of from $1 \mathrm{~cm}$. to $2 \mathrm{~cm}$. surrounding the externul os ras eroded and of a hright rose-red color. The whole surface of the cervix was hnrdened, indurated, nad bled easily to touch, and in some respects resemhled in uppearance the heginuing cauliflower-like epithelioma of the portio vaginalis. On making a closer examinution the cervical cunal was found dilnted, ndmitting the tip of the index finger. The finger detected un irregular, papillary growth, the size of a hickory-nut, urising from the posterior wall of the cervical canal just within and without the externul os. It grew from rather $n$ hroad surfuce, perhnps $1.5 \mathrm{~cm}$. in dinmeter, filled and dilnted the cervical cannl, and protruded on to the raginal surface of the posterior lip.

This growtl was of the snmc character as the less extensive disensc spoken of as erosion, which extended from the cervical canal and surrounded the externul os in other directions. There rere no ulcers or necrotic changes demonstrable to the naked eye. The disease was strictly limitecl to the cervical canal nad portio vaginalis in a monner very similar to papillary erosion in the nulliparous cervix. The papille wcre snull, finger-like projections attached to a distinctly indurated uaderlyiag cerpical tissue. They were not friahle, but wcre clnstic to touch. Although the whole cervix was hard and indurated, it was not as resisting as that in any form of carcinoma. The hiceding caused hy pulpation was slight and resenbled that sometimes seen in the popillary erosion of laceration of the cervix. The uterus was retroverted to the second degree, slightly movable, nnd very smull in size. The left ovary was found prolapsed und adherent helind the uterus. There were no nodules to be felt along the course of the tuhe, although it was distinctly determiaed to be hurdened aud diseased. The right tule nud ovary wcre also strongly adherent nnd disensed, nud were demonstrable in immedinte relntion with the lnteral wnll of the uterus.

From the ahore history nnd the nppearance und structure of the diseased cervix the lesions were cousidered to be due to one of threc rare disenses - tuherculosis of the corvix, mulignnat adenomn of the cervix, or syphilis of the cervix.

lBecause of the age of the pntieut, the history of amenorrhoen in a iniliparous womnu, the fact thnt the growtl grew from the nucous nembrane of the cervical cannl nud not from the portio vaginalis, with 
the absencc of any tendeacy to friahility and with the presence of a half-elastic feeling to the disensed tissue, we were at once thoroughly couvinced that the disense was aot the caulifower-like epithelioma of the portio vaginalis, aor did it in any way resemhle the other forms of carcinoma of this portion of the nterus.

Since there was no history of syphilis to he gaiaed from the patieut or her hushand, nor local skin indication of this disease, and kaowiag the history of amenorrhcea and other symptoms antedatiag marriage would at least he more likely to he caused hy tuhercular disense, sjplilis was almost wholly excluded.

The long-continued ahsence of the menstrual flow, with the preseace of stroagly adherent tuhes and ovaries and a small uterus, were points against the diagaosis of inalignant adenoma of the cervix, yet we were by no mesns convinced that this disense was a ot present, for the growth originated in the cervical mucous memhrane.

The history of oaly fairly good health during a loag period, amenorhou with complete ahsence of the menstrual flow for six months, the presence of a papillary growth from the cervical canal in a young, aulliparous woman, associated with a small uterus and demoastrahly very chroaic tuhal disease, surrouaded with dease adhesioas, without history of origin, with also the satisfactory exclusion of the other diseases anmed, caused me to put dowa in the haspital record the prohahlo diagaosis of tuherculosis of tho cervix, retroversion of the uterus, and tuhcrculosis of the adaeza. Following our customary plan, however, a portion of the papillary tissue was excised and examined microscopically. This examination positively determined the disease to he the papillary form of tuherculosis, the specimea coataining the claracteristic miliury tuhercles and Langhans' giant cells.

The operation of thorough curettement, high amputation of the cervix, and hilateral salpiago-oöphorectomy was performed on Marcli 29,1899 . The permission for a more radical operation could not he gained from the patient.

The coavalesceace was a ormal, and at the time of writing, sixteea months after operation, she had gained many pouads in weight, and ao aew symptoms had developed. A physical exnnination of the chest and ahdomen determined aothing abnormal, there were ao indications of remainiag tubercular disease, and the patient was apparently perfectly healthy.

Macroscopic Examination. The portion of the vagianl cervix rcmoved hy amputatioa presented a cut muscle surface, a Emooth vnginal mucous memhrane surface, aad a surface covered with erosion or small papillary outgrowtlıs. The papillary growth began ahout 1 cm. within the cervical caaal, and extended out on the portio vaginalis as alrealy described. It was most extensive and hest developed on the 
posterior cervical wall aad posterior lip of the portio vagianlis, formiag liere a aodule tbe size of a small bickory-a ut. The andular growth was directly contiauous witb similnr but less developed growths surroundiag the cervical caaal and external os. They were flat papillary growths, an excessive papillary crosioa, composed of miaute fager-like projectioas, rose-red in color, elnstic yet firm ia coasisteacy, aad slowing a 0 iadication of degenerative changes. The Fallopinn tubes were those of a chronic endosalpiagritis. The ovaries were macroscopically a ormal.

Michoscopıc Examinatrox. Microscopic gectioas were cut longitudiaally, parallel with the direction of the cervical caual upon nll sides, extending tbe leagth of the cervix aaputated. Ia all of thesc sections the squnmous epithelium of the portio vagiaalis sbowed aa iuflammatory chaage, begiaaing by proliferatioa $1.5 \mathrm{~cm}$. from the external os nnd progressiag ia some places to complete destruction at the exterual 08. The cells wcre first distiactly outlined, thea becnme a lonogeneous mass, whiclı gradunlly dienppeared. Beaeath the squamous epithelium there was geaerully distributed an exteusive small rouud-celled iafiltration, with mauy leucocytes, which to some extcat infiltrated the squamous cpithelium layer. The pajillas spoken of as growing from the cervical caual beyond the exteraal os were slender fiager-like processes growing close togetber, covered with columuar and cuboidal cpithelinl cells. The stroma was infiltrnted with small rouad cells, polymorpbous leucocytes, and bere aad there a milinry tubercle, often coatniaing a typical Laughans ginnt cell. The underlying endometrium and a considerablo portion of the aew cell tissue showed the same character of changes. No degenerativo change was found in any section, but cousiderablo fibrous clinuge was always preseat, rnther indicating a begianiug chroaic fibroid tuberculosis.

A microscopic examiaation of the corporcal eadometrium and Fullopian tubes determiaed the same character and stnge of tubercular disease Sections from the cervix, corporeal endometrium, and Fnllopian tubes were stnined for tubercle bacilli, and ia ench a few bncilli were found aftcr several had been prepared.

The primary seat of iafection was aot determinable, but it is probable this case was oac of desceading tuberculosis.

Drsasosis. Chronic diffuse tuberculosis of the portio vagiualis, endometrium, and muscle tissuc of the cervix (tubercular papillnry hyperplastic cndocervicitis), tubcrculosis of the corporeal endometrium aad Fallopian tubes.

From a study of the literature, as beforc said, I have been ablc to collect sixty-eight-adding my own, sixty-a iae-cases of tubercular infection of the uterus bclow the iaternal os; tbirty of these were post-morten discoveries, associnted with far adraaced tubercular lesioas ia other 
pnrts of the genital tract ond distoot ports of tbe body ; two were postmortem discoveries of primary tuberculosis of the cervix (Friedlonder and Knufmann); twenty-two rere clinical obserrutions alonc-of thesc three were associoted witb lesions in otber ports of tbe geoitnl truct and distaot ports of the body; four with lesions in distoot ports of the body olone; six with lesioos in other parts of tbe genitol troct olone; and in nioe the diseose was locolized to the cervix vlone, or it is not stated as to wbether other ports were infected. Fifteen cases werc observed both clinically ood post-mortem, oll of which were associnted with tuberculosis in other ports of the body.

The ugc of the potieots was recorded in fifty-seveo cases as follows : From seventeeo to twenty years, 6 ; twenty-one to tliirty, 27 ; thirty-one to forty, 9 ; forty-ooe to fifty, 5 ; fifty-one to sixty, 5 ; sixty-ooe to seventy, 3; seveoty-one to seventy-nine, 3, sbowiog very distinctly thot the disease is most frequcot during the period of sexual octivity. There seems to be no relotion betwcen the cbarncter of tuberculosis and tbe oge of the potient.

The disense was localized to the portio vaginolis in nineteen cases and to the cervical canol in six enses. Io the remojojog forty-four ${ }^{\circ}$ cnses both the portio voginolis and cervical conol were infected.

Tho clioical choracter of the disease is to be distioctly divided into threo vorieties: tuberculor ulceration of the cervis, tuberculor popillory hyperplostic eodocervicitis, nod miliory tuberculosis of the cervix.

Ulcerative Forn. This variety appearcd as siogle, lorge, or as multiplo minutc (size of o linsecd) ulcers distributed over the portio vaginolis or cervicol caool, or as an ulcerative process quito completely excovatiog the cntire cervical canol and destroying the portio voginalis. The ulcerative process commonly surrounded the externol os, exteodiog oloog the cervical canol aud over the portio vagioolis. In other cases nn ulcer wng seen on the portio vaginnlis, surrounded hy normal mucous membrane. The ground of the ulcers was usuolly whitc to yellowish in color. When of any size they were excavated, with shorp edges. The cervix wos often bypertrophied. Mlicroscopically o necrotic surfoce was seeo, beoeoth which were all of the usual tissue chonges of chronic diffuse tuberculosis. This tubercular change was in the early cases locolized to the mucous membraoe ond the immediote uodcriying musclo tissue of the cervix, but io the for ndvanced cases the nuscle tissue wos destroyed to extensive excavotion, even to olmost completc destruction of oll cervical tissue. Bocilli wcre sought for ood found in the tissue io sixteen cases, in the voginol dischorge in one case. In two instaoces they were diligeotly sought for, but could not be found.

Tubercular Papillary Hyperplastic Endocervicitis. This form of tuberculosis involved the cervical endometrium, porticnlarly the lower 
lalf of the endometrium, aud extended out onto the portio vaginalis, as does the common papillary erosion. Such erosion, however, is cxces. sively hyperplastic, and quite frequently forms a tumor, which in one instance reached the size of an apple (Emanuel). The cervix was always lypertrophied and usually irregular in shape. It was indurated, hut elastic. The growth was composed of small, finger-like projections, rose-red in color. Rarely, slight indications of caseation were seen.

The inicroscopic pathology of some of the cases described shows there is much evidence thnt in the beginning the disense is here $n$ tuherculnr catarrhal endocervicitis, extending to the gland structure, often causing excessive hypertrophy and hyperplasin of the gland cells, even to a cliange into epitbelioid cells and miliary tuhercles. At other times the gland cells were little changed, and the tuhercular process was most pronounced in the stroma tissue. The stromn tissue was almays more or less involved. The microscopical character was, except in two iustances, a chronic diffuse tuherculosig. In these two cases it was a beginning chronic fihroid tuberculosis. From the various descriptions, and with the careful study of my own case, it would seem to me that, aside from the presence of tuhercular tissue, the macroscopic character of this variety strongly resemhles tbe papillary erosion of Ruge and Veit, with excessive hyperplasin of nll structures, giving the macroscopic appearance of papillary or even small cauliflower-like outgrowths. It is not a vegetative or papillomatous growtl, as described by Cornil, Vitrac, Frinkel, and otbers, but, in tbe sense of Ruge and Veit, nn excessive papillary erosion caused by the infection of the tubercle bacillus.

Tubercle hacilli have been found in the tissue in eigbt of the fourteen cases reported. Bacilli were diligently sought for by $Z$ weifel and Michnelis, but not found.

Miliary Tuberculosis of the Cerviz. Two cases of this variety have been reported (Vircbow and Rigal-Cornil). Tbey are cbaracterized by the presence of minute milinry tubercles scattered over the portio vaginalis, associated with extensive and advanced tuherculosis on other parts of the body.

The large majority of the cases of tuherculosis of the cervix thus fnr descrihed bave heen secondary infections, there heing only three positive instances where it was satisfactorily proved that no other organ or tissue was involved. (I refer to the cases of Friedlander, Kuufmann, and Micbnelis.) Cases of possihle primary infection of the cervix, with secondary infection of other parts of the genital tract or hody, are those of Emanuel, Meyer, Zweighaum, Derville, Vitrac, and Bouffe.

Symptomalology. The subjective symptoms of tuherculosis of the cervix are iudefinite and iu no way characteristic of the disense. In 
most instances the symptoms have heen referahle to lesions in the uterus, tuhes, or peritoneum. The patients were mostly well-nourished and in good physical condition. Rarely they were anamic nnd had failed in health. Alany complained of malnise, indefinite and irregular pains in the lower ahdomen, a feeling of weight in the pelvis, and more or less sacral hackache.

The most frequent symptom in those cases carefully ohserved has been nn nhnormally profuse purulent leucorrhøa, now and then tinged with hlood. Leucorrhen was a symptom in twenty.four of the thirtyseven cases ohserved clinically.

Menorrhagin was present in thirteen cases. In four of these the uterus was much enlarged; nne contained a fihroid tumor, and in two retroversion of the uterus was present.

-Amenorrhœn was present in twelve cazes. In five of these the uterus was ahnormally small and in one grently enlarged.

In three cases where the menstruation was nornal the uterus was of normal size.

It would seem that to a great extent menorrhagia and amenorrhagia in tuherculosis of the cervix rere dependent upon the presence of lyperplasia and nplasia of the uterus or independent disense of the uterus.

The ohjective symptoms depend upon the form of the tuhercular lesion, the appearance varying as described in the consideration of their pathology.

The two varieties of clinical importance are the tuhercular papillary hjperplastic endocervicitis and the ulcerative form. The disease of the cervix in these cases, perhaps, at first sight resembles either the cauliflower cpithelioma or the excavating crater-like carcinoma of the cervix; hut taking my own experience in the first vnriety, and accepting the description of other authors in the second variety, I would very positively say that there are many distinct charncteristics of difference hetween carcinoma and tuherculosis of the cervix. However, since the expericnce of any one observer of this disense has been narrow, I am unahle to ahsolutely contradict the statement of Pean and others who hnve described such cases as having nll of the ohjective symptoms of carcinomn; yet I believe, if n careful examination of the cervix is made hy an experienced clinician, these disenses can generally he sepnrated one from the other.

The papillary form of tuberculosis of the cervix hleeds to touch, hut not so early or to the same extent as carcinoma of the cervix. The bleeding mny he compared to that sometimes seen in papillary erosion of the lacerated cervix. The tissue in tuherculosis of the cervix is not easily broken or friahle, hut has an elastic, velvety feeling, which is never present in carcinoma. Induration is present, but it is not the 
hard, resisting induration of adeacenrcinoma. Oa the other land, the tissue is more resisting than that of epithelioma of the portio vngianlis. Ia most cases of the papillary variety the tissue of thc portio vaginalis is lobulated, the vagiaal cervix irregular in slıape, aad the papillnry tissue usually fills and exteads from the cervical caal. The ulcentive form is a more or less exteasive necrosis, an ulcer or ulcers, with sharp, well-defined edges covered with caseous tissue. Here, too, the tissue hus an elastic fecling. The friability of carcinomatous tissue is absent, and the induration differs distiactly from carciaoan. The history, agc of patient, aad duration of disesse are important factors of diagaosis.

The tubercular papillary hyperplastic endocervicitis resembles in appearance and structurc excessive aon-tuhercular papillary erosion of thc cervix, and the prescace of euch an erosion witb early hleeding -particularly where there is a history of tuberculosiz-should be the cause for suspicion of tuberculosis and indicate microscopic examiantiou before treatmeat is cousidered. The tuherculsr papillary erosion also resembles ia appearaace and structure thc rare cases of maligant adenoma of the cervix.

Further, this form in many respccts resembles the syphilitic condyloma of the cervix.

The-ulcerative fora resembles ayphilitic chancre, chaacroid ulcus rodens, or carciaoma of the cervix. The method of differential diagnosis ia the first two instances will be appareat; iu the latter instances by the objective symptoms and a microscopic cxaminatioa.

As in early carcinoma of the cervix, a diagnosis of tuberculosis of the ccrvix must always he that of suspicion, made positive hy microscopic examiantion of excised tissue. This was the method of diaga osis in ten of the cases referred to.

The cliaical diagnosis in fifty-six of the cases reportcd in the litcrature was as follows: Carcianma or suspected carciaoma, 14 ; sarcoma, 1 ; ulcer of cervix, 4 ; ulcus rodeas, 1 ; vegctative growth of cervix, 1 ; indefiaite disense of the cervix, 2 ; phthisis or tubercular peritouitis, 28 ; tubercular meaingitis, 1 ; apoplexy, 1 ; abdomianal tumor, 2 ; caries of spiae, 1 .

Treatarest. The treatment of tuberculosis of the cervix must be to a very great exteat ideatical with that of tuberculosis of the Fal lopian tubes, ovaries, and uterine body-ng a rulc, operative. In those cases where thcrc are cxtcusive tuhcrcular lesions iu other parts of the body, or wherc the geaital tuberculosis is only a miaor cause of the patient's ill health, no trentmeat aside from local applicatioa or canterization of the cervix is iadicated. If there exists a lateat tuherculosis ia anotbcr part of the body which caaaot be iafluenced to acute re-developmeat by the necessary operative mensures, and the lesionis of the genitals are the chief cause of the patient's illness, then the trentmeat should bc radical 
operation-panhysterectomy. Should there he tuberculosis of the Fallopinn tuhes, ovaries, or uterus, with tuherculosis of the cervix, agoin panliystcrectomy should he the operation of election, though, as in my own case, amputation of the cervix, curettement, and hilateral salpingo. oöpliorectomy has as well effected n cure. Tuberculosis localized to the cervix and corporeal endometrium is hest treated hy panhysterectomy, but curettement and amputation have effected n cure. Primary isolated tuberculosis of the cervix is to he treated in a similar manner, hut panhysterectomy is less imperative. Local npplication and cauterization are at best only palliative, and should be condenned except in those cases where there is advanced tuhercular disease in other parts of the hody.

Fifteen of the cases referred to in this paper were treoted hy surgical ucans: Ten hy panhysterectomy ; one hy curettement, nmputation of the cervix, and hilateral salpingo-oôphorectomy : and four hy nmputation of the cervix. Local applications were npplied in eleven cases.

Where the operation was panhysterectomy, eeven completely recovered; six are doing well after five and $n$ half years; one after four mouths. Three died : one of shock following operntion, one of phthisis, one of tubercular peritonitis. Where amputation of the cervix was the opcration, two recovered and remoined well, ond two died of phthisis. In the case where bilateral salpingo-0ophorectomy, curettement, and auputation of tle cervix were performed the patient was healthy, apporcntly free from tuherculosis, sisteen months after operation. Where local application, cauterization, was the treatment, one is said to lave recovered, fivc rere temporarily improved, and in five the disense progressed.

I am indebted to Dr. F. I. Williarns for the preparation of tho microscopic sections and much assistance in their study. A complete report of this study of tuberculosis of the portio vaginalis and cervix uteri will appear at a Inter date.

\title{
REMARKS ON THE DIAGNOSIS OF SOME FORMS OF OPHTHALMIOPLEGIA.
}

\author{
BY L. F. ADT, M.D.,

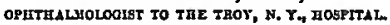

I DEsire to correct somo errors in the rules laid down by certain authors which are supposed to guide us in locating lesions affecting the ocular muscles governed hy the third nerve, more particularly thosc lesions involving the nucleus of the third nerve and those involving the root filres of this nerve in the tegmentum of the crus cerehri. 